\title{
Evaluation of Impact Strength of Polyamide 6/Bentonite Clay Nanocomposites
}

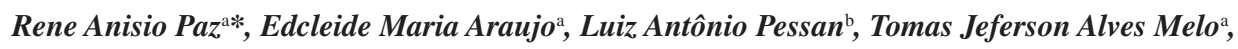 \\ Amanda Damião Leite ${ }^{\text {a }}$ Vanessa da Nobrega Medeiros ${ }^{\mathrm{a}}$ \\ ${ }^{a}$ Centro de Ciências e Tecnologia - CCT, Federal University of Campina Grande - UFCG, \\ Av. Aprígio Veloso, 882, Bodocongó, CEP 58429-900, Campina Grande, PB, Brazil \\ ${ }^{\mathrm{b}}$ Materials Engineering Department - DEMa, Federal University of São Carlos - UFSCar, \\ Rod. Washington Luís, SP-310, Km 235, São Carlos, SP, Brazil
}

Received: March 24, 2011; Revised: March 17, 2012

\begin{abstract}
Nanocomposites of polymer/clay have had much attention in recent years, particularly those developed with layered silicates due to the need of engineering materials more efficient than pure polymers for certain applications. The level of exfoliation of layered silicates in crystalline structure of polymer matrices has been studied and has been observed that it affects the crystalline behavior and the physical and mechanical properties. In this study, nanocomposites of polyamide 6 were obtained by the melt intercalation method, using a Brazilian bentonite modified with a quaternary ammonium salt. X-Ray Diffraction (XRD) results showed the incorporation of salt among the layers of clay, making it organophilic and that the nanocomposites presented exfoliated and/or partially exfoliated structures and confirmed by transmission electron microscopy (TEM). By thermogravimetry (TG), the results indicated that the presence of clay increased the thermal stability of polyamide 6 . The impact properties of the nanocomposites showed inferior values in relation to the pure polyamide, in other words, decrease the toughness.
\end{abstract}

Keywords: nanocomposites, organoclay, polyamide 6

\section{Introduction}

In recent years there has been much attention given to polymer-clay nanocomposites, particularly those developed with layered silicates due to the need of more efficient engineering materials, and because of the fact that pure polymers do not present the properties needed for certain applications. Several methods have been applied for the preparation of polymer-clay nanocomposites, such as melting intercalation, the most used among them ${ }^{1}$.

Polymeric nanocomposites are hybrid materials where inorganic nanosized substances are dispersed in a polymer matrix $^{2-3}$. Polymer layered silicate nanocomposites are compared to conventional polymeric composites due to the use of fillers to improve some specific properties ${ }^{1}$. Such nanocomposites present improvement on mechanical, thermal, flammability and dimensional stability properties, using low concentrations of silicate, around $1-5 \%$ by weight ${ }^{4}$.

From the surveys conducted by the Toyota group which developed polyamide 6 nanocomposites using small amounts of montmorillonite clay and obtained a significant increase in mechanical and thermal properties, several other studies have been conducted in order to achieve synergy among the parts ${ }^{5,6-12}$.

Layered silicates which are used as fillers present particles with nanometric dimensions (100-500 nm) and have a high surface area which promotes better interaction

*e-mail: rene@cct.ufcg.edu.br with the polymer matrix and therefore an improvement in physical properties ${ }^{5}$. Several polymers have been used in the preparation of polymer-clay nanocomposites, such as polystyrene, polyamide 6 and 66 , polycarbonate, polyolefins, etc ${ }^{13}$. The effect of the presence of layered silicates and the level of exfoliation of the crystalline structure of polymer matrices have been studied and it has been observed that they affect crystalline behavior and hence physical and mechanical properties ${ }^{14}$. The objective of this work was to analyze the effect of the Brazilian clay incorporation on the mechanical strength under the impact of polyamide 6/bentonite clay nanocomposites.

\section{Materials and Methods}

\subsection{Materials}

Bentonite clay Brasgel PA (sodium), with CEC $($ cation exchange capacity $)=90 \mathrm{mEq} / 100($ method of adsorption of methylene blue) passed through ABNT sieve no. $200(\mathrm{D}=74 \mu \mathrm{m})$, cream colored, supplied by Bentonit União Nordeste (BUN) located in Campina Grande-PB. The clay was called untreated clay (MMT) because montmorillonite is the predominant clay mineral.

The polymer matrix used was a polyamide 6 (Technyl C216) provided by Rhodia/ SP, in the form of white pelets.

We used the quaternary ammonium salt Cetremide (hexadecyltrimethyl ammonium bromide), produced by Vetec/SP. 


\subsection{Methods}

To make clay compatible with the polymer matrix, the sodium ions present between the layers of clay were exchanged for ions of the quaternary ammonium salt (Cetremide) to produce the organoclay, called OMMT. This exchange was performed in the presence of the quaternary ammonium salt Cetremide. To obtain organoclay (OMMT) a suitable treatment was conducted for the salt, based on the CEC of clay, according to procedure reported in previous studies $^{2,4,14}$.

Before any processing step, all materials containing polyamide were dried at $80{ }^{\circ} \mathrm{C}$ for 24 hours in the vacuum oven.

To obtain nanocomposites we used a preparation of a concentrate of polyamide and clay (1:1) in an internal mixer coupled to a Torque Rheometer System 90 by Haake-Büchler, operating at $240{ }^{\circ} \mathrm{C}, 60 \mathrm{rpm}$ for 10 minutes. The concentrate obtained was crushed in a grinder of knives and then added to the polymer matrix in quantities necessary to obtain nominal concentrations of $3 \mathrm{wt}(\%)$ clay.

The mixture polyamide 6/organoclay was processed in a corrotational Werner-Pfleiderer ZSK 30 twin screw extruder at a temperature of $220^{\circ} \mathrm{C}$ on the $1^{\text {st }}$ zone and $240{ }^{\circ} \mathrm{C}$ on the other heating zones. We used two rotational speeds of the threads 100 and $200 \mathrm{rpm}$, feed rates of 5 and $10 \mathrm{~kg} / \mathrm{h}$ and two screw profiles R1 and R2.

The threads are composed of various transport elements, but the difference between them is in the mixing zone. For comparison, pure polyamide 6 was extruded under the same mixing conditions, at a feed rate of $5 \mathrm{~kg} / \mathrm{h}$.

Samples were named as 5100R1, which means, feeding rate of $5 \mathrm{~kg} / \mathrm{h}$ speed of $100 \mathrm{rpm}$ and R1 screw. The other samples follow the same naming pattern. The changes in rotational speed, thread profile and feed rate were conducted to evaluate the effect of these processing variables on the structure and mechanical behavior of the polyamide 6 nanocomposites obtained.

After extrusion, the material was granulated and dried at $80{ }^{\circ} \mathrm{C}$ in the vacuum oven for 24 hours, and processed by injection moulding in an Arbug Allrounder 270/30 t machine. The specimens were prepared for tensile and impact testings according to the ASTM D638, D256, respectively.

The clay and the nanocomposites were characterized by $\mathrm{X}$-ray diffraction (XRD). Moreover, the nanocomposites were also characterized by transmission electron microscopy (TEM), thermogravimetry (TG) and mechanical properties.

\section{Results and Discussion}

\subsection{X-RAY Diffraction (XRD)}

To evaluate the formation of polyamide 6/organoclay nanocomposites, the systems were characterized by XRD. Figure 1 shows the XRD diffraction patterns for polyamide 6 (PA6) and the PA6/organoclay (OMMT) systems. The XRD curve for OMMT clay is also shown for comparison. It is noticed that the peak of the organoclay with $\mathrm{d}_{001}=21.34 \AA$ disappeared when it was incorporated into the polyamide 6 matrix and apparently a small shoulder appeared for all nanocomposites around 6.2 degrees. These results may indicate that all systems showed exfoliated and/or partially exfoliated structures, similar results were found in the literature ${ }^{5,10,11}$. It is interesting to notice that the nanocomposites patterns presented the same behavior regardless the processing variables used. These results are consistent with other works reported in the literature ${ }^{15,16}$.

\subsection{Transmission Electron Microscopy (TEM)}

The transmission electron microscopy was used to analyze the morphology of the nanocomposites and to confirm the X-ray diffraction results. Figure 2 shows

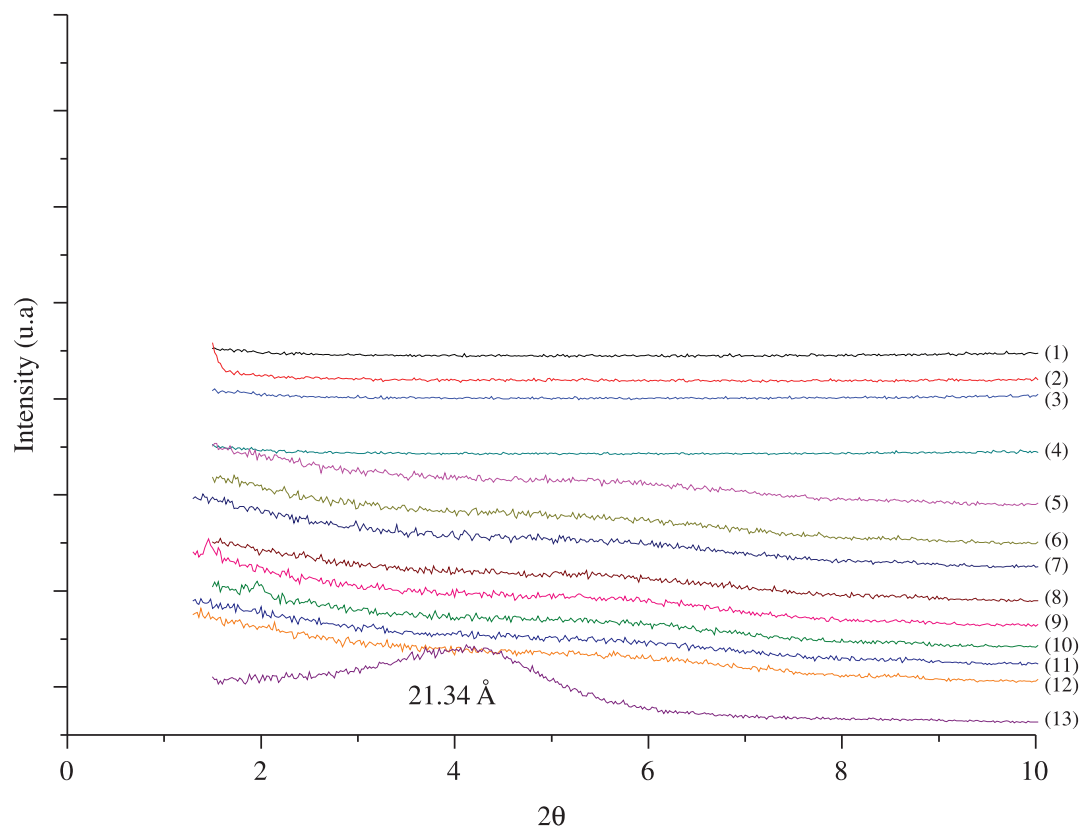

(1) PA $65100 \mathrm{R} 1$

(2) PA 65100 R2

(3) PA 65200 R1

(4) PA 65200 R2

(5) NANO 5100 R1

(6) NANO 5100 R2

(7) NANO $5200 \mathrm{R} 1$

(8) NANO 5200 R2

(9) NANO $10100 \mathrm{R} 1$

(10) NANO 10100 R2

(11) NANO $10200 \mathrm{R} 1$

(12) NANO 10200 R2

(13) OMMT

Figure 1. XRD patterns of organoclay, polyamide 6 and PA6/organoclay systems. 
representative images obtained for all compositions. They present morphologies composed of exfoliated clay lamellae and well distributed in the polymer matrix. Similar results were observed in the literature ${ }^{5,10,16}$ with nanocomposites obtained from commercial clays These images corroborate the results of X-ray diffraction.

As expected, the presence of the salt on the surface of the clay can change from hydrophilic to hydrophobic characteristic improving the wettability between PA6 and organoclay and promoting the exfoliation of clays in the PA6 matrix.

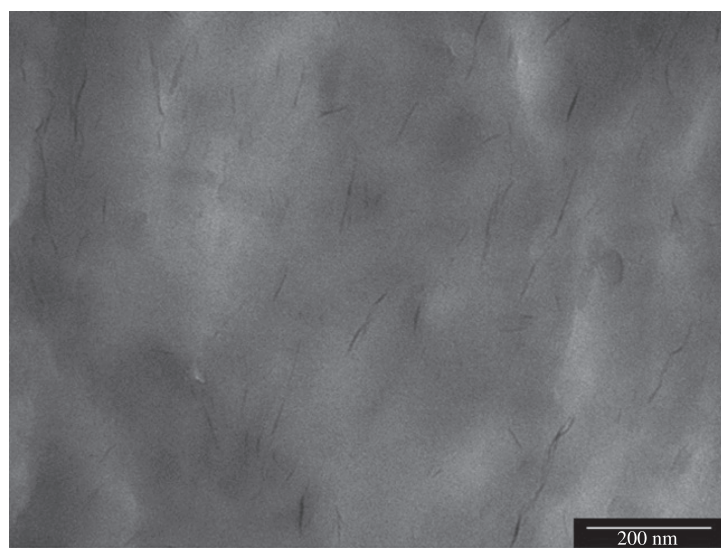

(a)

\subsection{Thermogravimetry (TG)}

TG curves of PA6 and its nanocomposites are shown in Figure 3. An important feature to note is that all samples present the decomposition steps. It can be observed that the clay almost not changed the degradation temperature of the pure polymer. Close to $200{ }^{\circ} \mathrm{C}$ appears an event that may be associated with the decomposition of organic salt and some moisture. Above $400{ }^{\circ} \mathrm{C}$ begins to appear decomposition or other events of mass loss that may be related the polymer matrix. These results indicate that the presence of clay maintained the thermal stability of polyamide 6 .

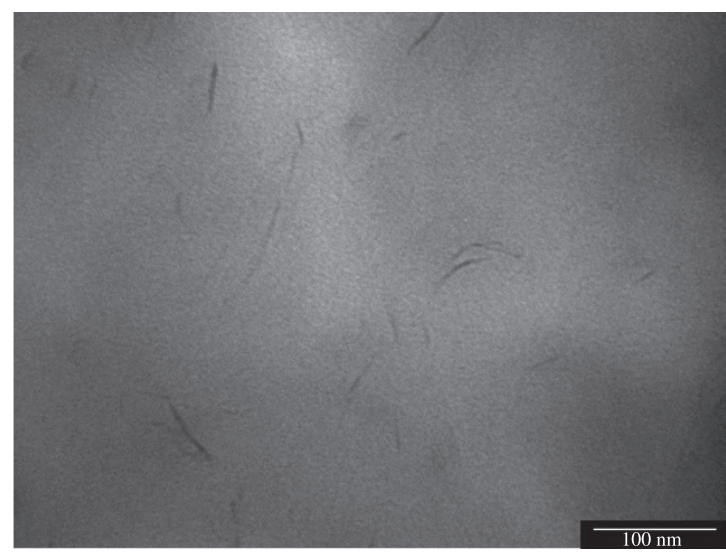

(b)

Figure 2. TEM photomicrographs of PA6/organoclay nanocomposites.

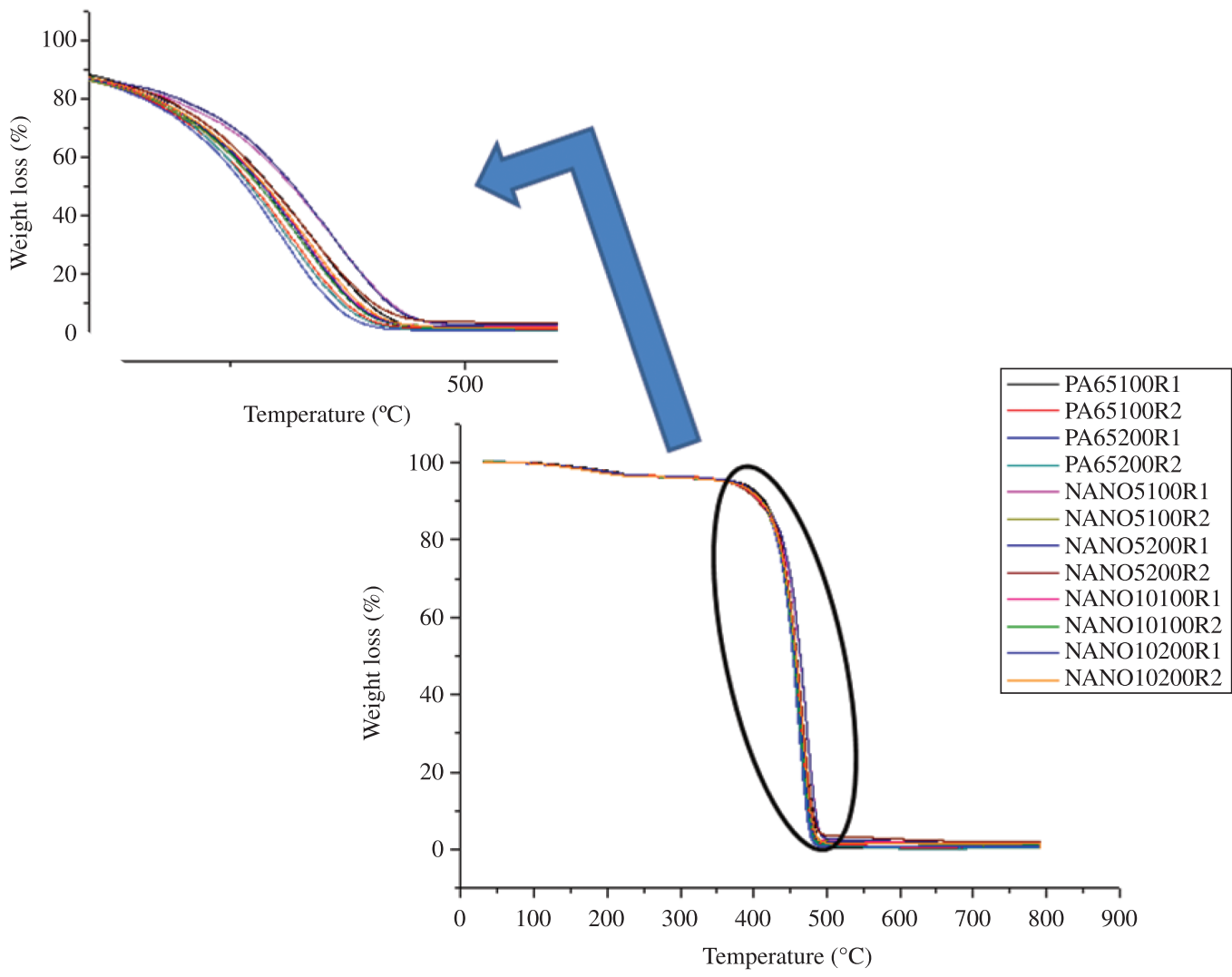

Figure 3. TG curves of polyamide 6 and its nanocomposites. 
Table 1. Young modulus and impact strength of polyamide 6 and its nanocomposites.

\begin{tabular}{ccc}
\hline Sample & $\begin{array}{c}\text { Young modulus } \\
(\mathbf{G P a})\end{array}$ & $\begin{array}{c}\text { Izod impact } \\
\text { strength }\left(\mathbf{J . m}^{-1}\right)\end{array}$ \\
\hline PA6 5 100 R1 & $2.9 \pm 0.1$ & $41.0 \pm 4.5$ \\
PA6 5 100 R2 & $2.9 \pm 0.2$ & $47.0 \pm 2.7$ \\
PA6 5 200 R1 & $3.3 \pm 3.2$ & $40.8 \pm 3.2$ \\
PA6 5 200 R2 & $3.4 \pm 0.3$ & $44.3 \pm 5.8$ \\
NANO 5 100 R1 & $3.5 \pm 0.1$ & $34.7 \pm 4.1$ \\
NANO 5 100 R2 & $3.6 \pm 0.1$ & $39.4 \pm 2.5$ \\
NANO 5 200 R1 & $3.5 \pm 0.1$ & $33.9 \pm 2.7$ \\
NANO 5 200 R2 & $3.7 \pm 0.0$ & $35.5 \pm 1.7$ \\
NANO 10 100 R1 & $3.5 \pm 0.1$ & $36.2 \pm 3.1$ \\
NANO 10 100 R2 & $3.6 \pm 0.0$ & $35.7 \pm 2.6$ \\
NANO 10 200 R1 & $3.6 \pm 0.1$ & $30.6 \pm 2.7$ \\
NANO 10 200 R2 & $3.5 \pm 0.1$ & $35.4 \pm 3.7$ \\
\hline
\end{tabular}

\subsection{Izod impact on mechanical testings}

According to Sinha Ray and Okamoto ${ }^{5}$ and Alexandre and Dubois ${ }^{13}$, the polymer-clay systems containing low clay content $(<10 \%)$ present better mechanical properties compared to pure polyamide. This increase is due to stronger interfacial interaction between the matrix and the layers of clay.

Table 1 shows the elastic modulus and the impact strength of pure polyamide and its nanocomposites. It can be observed that nanocomposites showed a reduction

\section{References}

1. Ganguli S, Dean D, Jordan K, Price G and Vaia R. Mechanical properties of intercalated cyanate ester-layered silicate nanocomposites. Polymer. 2003; 44(4):1315-19. http://dx.doi. org/10.1016/S0032-3861(02)00709-7

2. Barbosa R, Araújo EM, Maia LF, Pereira OD and Melo TJA. Morphology study of polyethylene and nylon 6 nanocomposites containing national clay. Polímeros. 2006; 16(3):246-251.

3. Araújo SS, Paiva GP, Carvalho $1 \mathrm{H}$ and Silva SML. Nanocompósitos PP/Betonita empregando uma bentonita de wyoming tratada com três diferentes tipos de sais quaternários de Amônio. Matéria. 2004; 9(4):426-436.

4. Barbosa R, Araújo EM, Oliveira AD and Melo TJA. Efeito de sais quaternários de amônio na organofilização de uma argila bentonita nacional. Cerâmica. 2006; 52(324):264-8. http:// dx.doi.org/10.1590/S0366-69132006000400009

5. Sinha Ray S and Okamoto M. Polymer/layered silicate nanocomposites: a review from preparation to processing. Progress in Polymer Science. 2003; 28(11):1539-41. http:// dx.doi.org/10.1016/j.progpolymsci.2003.08.002

6. Leite AMD, Araújo EM, Lira HL, Barbosa R and Ito EN. Obtaining microporous membranes from nylon 6/national clay nanocomposites. Part 1: influence of clay on the membranes morphology. Polímeros. 2009; 19(4):271-77.

7. Brito GF, Oliveira AD, Araújo EM, Melo TJA, Barbosa R and Ito EN. Polyethylene/national bentonite clay nanocomposites: influence of clay and PE-g-MA coupling agent on the mechanical properties and flammability. Polímeros. 2008; 18(2):170-177.

8. Chiu FC, Lai SM, Chen YL and Lee TH. Investigation on the polyamide 6/organoclay nanocomposites with or without a maleated polyolefin elastomer as a toughener. Polymer. 2005; 46(25):11600-11609. http://dx.doi. org/10.1016/j.polymer.2005.09.077 of around $10 \%$ on average in impact strength, ie, loss of toughness, when compared to the pure polyamides. This can be attributed to the greater rigidity of these systems ${ }^{8}$. These results were also confirmed by an increase on the Young modulus and can be attributed to the occurrence of dispersion of silicate layers in polymer matrix and strong interactions of functional groups of PA6 with the clay surface, as reported in the literature ${ }^{5}$.

\section{Conclusions}

Polyamide 6/organoclay nanocomposites were obtained with success by melt intercalation technique. By X-ray diffraction was possible to observe exfoliated and/or partially exfoliated structures. By transmission electron microscopy, all the nanocomposites exhibited morphologies exfoliated clay lamellae and well distributed in the polymer matrix. The results from thermogravimetry analysis indicated that the presence of clay almost not changed the thermal stability of polyamide 6 , and mechanical characterization under impact showed that the nanocomposites presented inferior properties compared to pure polyamide, that is, loss of toughness. The results also indicated an increase on the Young modulus.

\section{Acknowledgements}

The authors thank Rhodia/SP, Bentonit União Nordeste (BUN), DEMa/UFCG andDEMa/UFSCar, CAPES/PROCAD/ NF, MCT/CNPq and RENAMI, for financial support.

9. Cho JW and Paul DR. Nylon 6 nanocomposites by melt compounding. Polymer. 2000; 42:1083-1094. http://dx.doi. org/10.1016/S0032-3861(00)00380-3

10. Fornes TD and Paul DR. Crystallization behavior of nylon 6 nanocomposites. Polymer. 2003; 44(14):3945-3961. http:// dx.doi.org/10.1016/S0032-3861(03)00344-6

11. Fornes TD, Yoon PJ, Keskkula H and Paul DR. Nylon 6 nanocomposites: the effect of matrix molecular weight Polymer. 2001; 42(25):9929-9940. http://dx.doi.org/10.1016/ S0032-3861(01)00552-3

12. Alexandre M and Dubois P. Polymer-layered silicate nanocomposites: preparation, properties and uses of a new class of materials. Materials Science and Engineering. 2000; 28(1-2):1-36. http://dx.doi.org/10.1016/ S0927-796X(00)00012-7

13. Paz RA, Araújo EM, Melo TJA, Pereira OD and Barbosa R. Nanocompósitos de poliamida 6/argila bentonita: efeito do peso molecular da matriz no comportamento reológico e na estrutura. REMAP-Revista Eletrônica de Materiais e Processos. 2007; 5:08-11.

14. Araújo EM, Barbosa R, Rodrigues AWB, Melo TJA and Ito EN. Processing and characterization of polyethylene/Brazilian clay nanocomposites. Materials Science \& Engineering: A. 2007; 141:445-449.

15. Paz RA. Desenvolvimento de nanocompósitos de poliamida 6 com argila organofilica. [Tese]. Campina Grande: Universidade Federal de Campina Grande; 2011.

16. Leite AMD, Araujo EM, Paz RA, Pereira OD, Lira HL and Ito EN. Structure and mechanical properties of polyamide 6/Brazilian clay nanocomposites. Materials Research. 2009; 12(2):165-168. http://dx.doi.org/10.1590/ S1516-14392009000200009 